\title{
THE DIAGNOSTICS AND WAYS HEAT TREATMENT OPTIMIZATION OF A RAILWAY WHEELS STEEL
}

\author{
Volodymyr VIRA ${ }^{1}$, Volodymyr KULYK ${ }^{1}$, Roman CHEPIL ${ }^{2}$, \\ Yevhen KHARCHENKO ${ }^{1,3}$, Zoia DURIAGINA ${ }^{1,4}$ \\ ${ }^{1}$ Lviv Polytechnic National University, S. Bandery Str. 12, 79013 Lviv, Ukraine \\ ${ }^{2}$ Karpenko Physico-Mechanical Institute of the NAS of Ukraine, Naukova Str. 5, 79060 Lviv, Ukraine \\ ${ }^{3}$ University of Warmia and Mazury in Olsztyn, Faculty of Technical Science, Oczapowskiego str. 11, \\ 10-736 Olsztyn, Poland \\ ${ }^{4}$ The John Paul II Katholic Uniwersity of Lublin, Faculty of Physical Chemistry and Physicochemical \\ Fundamentals of Environmental Engineering, Racławickie Al. 14, 20-950 Lublin, Poland \\ viravolodymyr@gmail.com, kulykvolodymyrvolodymyrovych@gmail.com, romanchepil68@gmail.com, \\ kharchen@wp.pl, zduriagina@ukr.net
}

\begin{abstract}
A high resolution sensor of linear displacements has been elaborated for diagnosing the size of the crack tip opening in standard test specimens. Based on the data measured during fatigue crack growth resistance tests of a wheel steel heat treated after various modes, calculations of the strain and energy parameters of local fracture were performed for the corresponding variants of treatment, and fatigue crack growth rate diagrams were constructed using different approaches of fatigue fracture mechanics. It was established that the diagrams obtained using the strain and energy approaches are more sensitive to material microstructure and its mechanical properties than the traditional diagrams obtained using the stress approach. Based on the parameters of the fatigue crack growth resistance estimated using the strain and energy approaches, the effective diagnostics and the best heat treatment mode for the wheel steel was developed. It comprises the stages of isothermal quenching and tempering at a temperature of $500{ }^{\circ} \mathrm{C}$, providing the highest fatigue fracture toughness of the steel.
\end{abstract}

Keywords: railway wheel steel, local stress and strain, strain energy, fatigue crack growth

\section{DIAGNOSTYKA I KIERUNKI OPTYMALIZACJI OBRÓBKI CIEPŁNEJ STALI KÓŁ KOLEJOWYCH}

\section{Streszczenie}

Opracowano czujnik przemieszczeń liniowych o podwyższonej czułości dla diagnozowania rozwartości szczeliny na podstawie określenia odkształceń i energetycznych parametrów uszkodzenia lokalnego. W oparciu o różne podejścia mechaniki zniszczenia zmęczeniowego zostały skonstruowane diagramy prędkości propagacji pęknięć zmęczeniowych w stali koła kolejowego po różnych rodzajach obróbki cieplnej. Ustalono, że diagramy odporności na pękanie, otrzymane według odkształceniowego lub energetycznego podejścia, są bardziej wrażliwe do strukturalnych i mechanicznych własności materiałów w porównaniu z tradycyjnymi diagramami otrzymanymi według podejścia siłowego. Pokazano zalety odkształceniowego i energetycznego podejścia $\mathrm{w}$ porównaniu $\mathrm{z}$ podejściem siłowym $\mathrm{w}$ zakresie optymalizacji charakterystyk odporności materiałów na pękanie. Dokonano skutecznej diagnostyki stanu technicznego materiału oraz optymalizacji obróbki cieplnej stali kół kolejowych. Ustalono, że hartowanie izotermiczne z odpuszczaniem przy temperaturze $500^{\circ} \mathrm{C}$ zapewnia najwyższą odporność stali na pękanie.

Słowa kluczowe: stal kół kolejowych, naprężenia i odkształcenia lokalne, propagacja pęknięcia zmęczeniowego

\section{INTRODUCTION}

The integrity of the mechanical elements of the railway transport, ensuring their reliable and longlasting work, as well as reliable diagnostics of their residual service life, are important issues in today's engineering practice $[1,2]$. At the same time, railway wheels are the most determinative parts of the rolling stock, because the reliability of transportation and traffic safety depend directly of their condition. Therefore, they are subject to increased requirements at the manufacturing stage, and in the course of operation a permanent diagnostic of the material state is performed, on the basis of which a decision is made to extend the operational time, repair or replace the wheel pair. Various kinds of unacceptable damage (jags, sliders, wear and tear of the ridge) arise in railway wheels during operation. Therefore, the wheel periodically undergoes the turning process, which 
reduces the outer diameter of the wheel and significantly reduces its operating life. The uprise probability of such damage can be substantially reduced at the manufacturing stage, taking into account a variety of factors. Consequently, materials for the manufacture of railway wheels should meet a certain set of established requirements [3], that is, they should be of appropriate strength, hardness, impact strength, endurance, static fracture toughness, etc.

Regarding the latter parameter, it should be noted that the wheels operate under cyclic loading conditions. In existing norm documents, unfortunately, there are no characteristics of cyclic crack growth resistance, which (in our opinion) are considered in modern fatigue fracture mechanics as the most adequate basis for diagnosing fatigue service life and residual life of structural elements in the specified conditions of their operation [4]. In this case, the fatigue crack growth rate diagram which represents the relationship between the fatigue crack growth rate and a certain parameter characterizing conditions of its growth, is the main source for determining parameters of the material resistance against fatigue crack propagation under cyclic load. Such parameters can be the stress or stress intensity factor (in case of the stress approach), opening or deformation in the crack tip vicinity (the strain approach), and energy expenditure on material deformation and crack increment (the energy approach). The fatigue crack growth rate diagrams allow us to determine the characteristics of the fatigue crack growth resistance of materials which are used for prediction of fatigue service life and to estimate residual resource of construction elements. On their basis, it is also possible to make a selection, diagnostics or optimization of structural materials depending on the conditions of operation of the design. As a result, new materials are created with the necessary physical, chemical, and mechanical properties that meet the predefined requirements.

In regard of direct diagnostics, the stress approach is considered to be the most developed and investigated in chronological terms as well as by the currently acquired results. Its methods and means are standardized for constructing the dependences "the fatigue crack growth rate - the stress intensity factor (SIF) range" $(d a / d N-\Delta K)$ $[5,6]$. The SIF range describes the stress field in the crack tip using the applied load, the crack length and the geometry of a specimen. However, the influence of the scale factor and the crack closure phenomenon make their corrections to the kinetics of material fracture and do not allow unambiguously establish the crack growth rate, depending on the magnitude of $\Delta K$ for different asymmetries of the load cycle and specimen thickness [7, 8]. Thus, the stress approach has certain disadvantages and it is not always possible in engineering practice to adequately select or optimize the material for specific conditions of operation of the design. In addition, there may be difficulties in calculating stresses in structures of complex geometric shape.

From this point of view, the strain approach may be easier to use, since strain values can be determined both by calculation, using analytical methods, and experimentally by direct measurement on a specimen or structure. Among the analytical ones are the well-known approaches of Rice, Panasyuk, Troshchenko and others [9, 10], which are limited in practical use because of drawbacks they have. Consequently, unlike SIF, there is no adequate universal method for calculating the crack opening range and local strain, depending on the geometry of specimens, the crack length and the loading method, that is, there are no dependences similar to the K-calibration curves for the stress approach. Along with the analytical methods, experimental ones for determining the distribution of elastic-plastic strains in the crack tip vicinity are used [11-15]. For this purpose, smallsized strain gauges, a method of marks or coordinate grids, optical methods for direct observation, etc. are mainly used. Here the accuracy of measuring the local displacements, in particular the crack opening at its tip becomes of great importance. In this case, in order to avoid many disadvantages associated with the nonlinear distribution of elastic-plastic strains in the crack tip vicinity, it is recommended that the measurement of the opening should be carried out directly in the crack tip [16].

The logical symbiosis of stress and strain approaches is energy one [17-20]. The known parameters of the last are based on the area of the hysteresis loop and, in relation to the fatigue of materials, are studied in detail for smooth specimens. In the presence of a crack, the calculation of local stresses and strains, as well as the establishment of the shape of the loop turns into a rather complicated task. Here, among the energy criteria, the most famous is the method of the $J-$ integral, the theoretical basis of which does not fully reflect the features of the cyclic load. There are not much data in the literature on the dependence of the crack growth rate on the parameters of the mechanical hysteresis loop or on the range $\Delta J$, as compared to results obtained using the stress approach. At present, among the known energy parameters of fatigue fracture there are the energy of inelastic strain per cycle; the total strain energy per cycle, consisting of elastic and inelastic constituents; the total energy of inelastic strain for all cycles before fracture [21].

Based on the analysis of the known in the literature approaches aimed at determining the stress, strain and energy parameters that control the resistance of material to the fatigue cracks initiation and its growth, and also based on our own understanding of the processes of local fatigue fracture, we developed our own methods [22] for 
determination of such parameters, which are used for construction of the fatigue crack growth rate diagrams for the purpose of more effective diagnostics of material state and his optimization according to the characteristics of the fatigue crack growth resistance.

The purpose of this study is to construct fatigue crack growth rate diagrams for a railway wheel steel heat treated after various modes, based on the stress, strain and energy parameters of fatigue fracture mechanics, to highlight possible advantages of the energy and strain approaches over the stress one, and to optimize the heat treatment mode of the steel taking into account the most suitable parameters.

\section{MATERIALS AND PROCEDURES}

A high-strength wheel steel type $\mathrm{T}$ [23] of nominal chemical composition $0.63 \mathrm{C}, 0.72 \mathrm{Mn}$, $0.32 \mathrm{Si}, 0.094 \mathrm{~V}, 0.16 \mathrm{Cr}, 0.11 \mathrm{Ni}, 0.05 \mathrm{Cu}$ (the rest is $\mathrm{Fe}$ ) has been investigated, which is similar to type ER9 according to the European standard EN 13262. For this material it was not possible to unambiguously establish the optimum tempering temperature using fatigue crack growth resistance parameters in the framework of the stress approach [24]. The steel has been heat treated after various modes consisting of the stages of isothermal quenching at a temperature of $875^{\circ} \mathrm{C}$ and salt bathing at $375{ }^{\circ} \mathrm{C}$ for $1 \mathrm{~min}$, followed by tempering for $2 \mathrm{~h}$ at temperatures 450,500 , and $550{ }^{\circ} \mathrm{C}$. Mechanical characteristics of strength $\left(\sigma_{0.2}, \sigma_{\mathrm{B}}\right)$, plasticity $(\delta)$ and hardness (Table 1) were determined by us earlier [24].

Table 1. Mechanical properties of the investigated materials

\begin{tabular}{|c|c|c|c|c|c|c|}
\hline \multicolumn{2}{|c|}{$\begin{array}{l}\text { Material } \\
\text { heat } \\
\text { treatment } \\
\text { mode }\end{array}$} & $\begin{array}{c}\text { Yield } \\
\text { strength } \\
\sigma_{0.2}, \\
\mathrm{MPa}\end{array}$ & $\begin{array}{c}\text { Ultimate } \\
\text { strength } \\
\sigma_{\mathrm{B}}, \\
\mathrm{MPa}\end{array}$ & $\begin{array}{c}\text { Elongation } \\
\delta, \%\end{array}$ & $\begin{array}{l}\text { Hard } \\
\text { ness } \\
H B\end{array}$ & $\begin{array}{c}\text { Process } \\
\text { zone } \\
\text { size } \\
d^{*} \\
\mu \mathrm{m}\end{array}$ \\
\hline \multirow{3}{*}{ 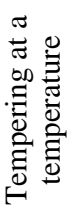 } & $\begin{array}{r}450 \\
{ }^{\circ} \mathrm{C}\end{array}$ & 772 & 1030 & 17,9 & 291 & 130 \\
\hline & $\begin{array}{c}500 \\
{ }^{\circ} \mathrm{C}\end{array}$ & 880 & 1076 & 16,1 & 287 & 140 \\
\hline & $\begin{array}{c}550 \\
{ }^{\circ} \mathrm{C}\end{array}$ & 746 & 987 & 17,6 & 288 & 150 \\
\hline
\end{tabular}

The size of the fatigue process zone $d^{*}$, which determines the length of non-propagated cracks or safety defects in the material and is a determining factor in the diagnosis of material damage or the determining parameter of the fatigue fracture process, was determined by changing the cross section of the specimen in the vicinity of the stress concentrator caused by plastic strain, using the method of laser interferometry [25].

Compact specimens (CT) of the steel with the base size $W=40 \mathrm{~mm}$ and a thickness of $11 \mathrm{~mm}$ were tested in the laboratory air on a universal burst BISS servo-hydraulic machine (maximum load $-50 \mathrm{kN}$, frequency- up to $50 \mathrm{~Hz}$ ) (Fig. 1) at a constant amplitude of the load, a frequency of 10$15 \mathrm{~Hz}$, and the asymmetry coefficient of the load cycle $R=P_{\min } / P_{\max }=0.1$. The length of the fatigue macrocrack and the moment of its initiation were fixed by an optical microscope KM-6 with $25 \mathrm{x}$ magnification with a measurement error of $\pm 0.02 \mathrm{~mm}$

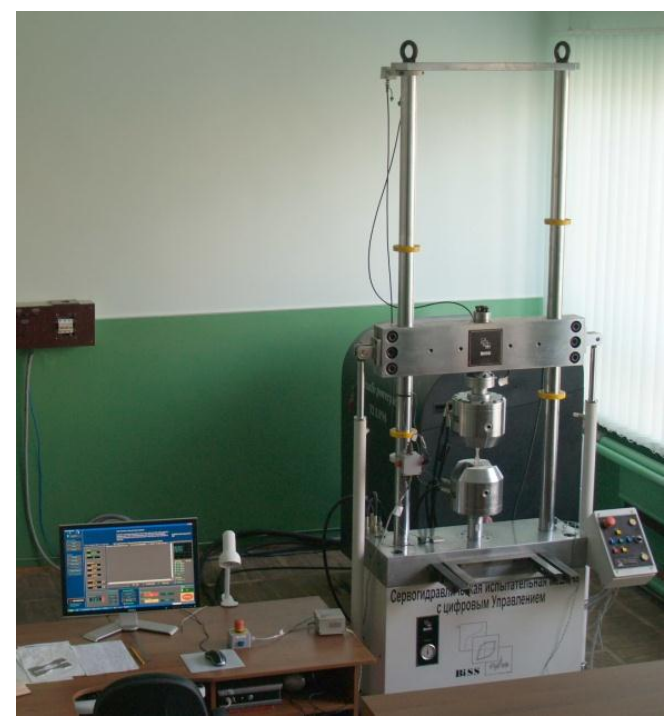

Fig. 1. The testing machine "BISS" for carrying out fatigue tests

For direct measurement of the crack tip opening, a measuring system was created consisting of a displacement sensor (Fig. 2 a) constructed on the basis of a semiconductor strain gauge (Fig. 2 b), and an analog-to-digital converter (ADC) which outputs a current signal in-time on a personal computer (PC) monitor (Fig. 3).
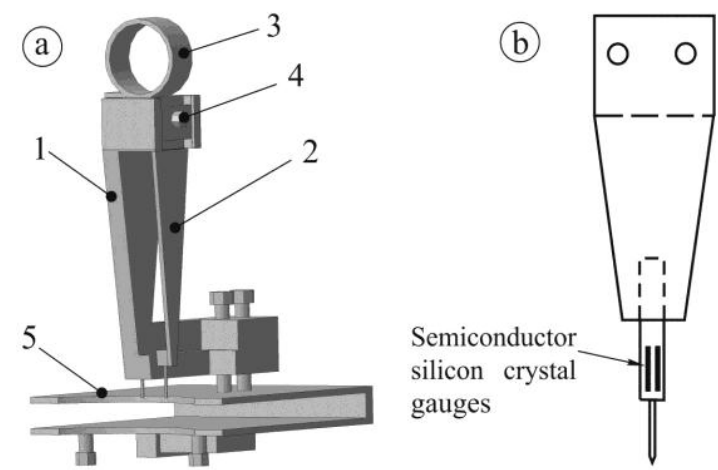

Fig. 2. The displacement sensor (a) and the construction of its strain gauge beam (b). 1 - fixed arm, 2 - movable arm, 3 - elastic ring, 4 - fixing screw, 5 - holder

A load applied to a test specimen is measured with the dynamometer, and a current signal is also transmitted to a PC. The main feature of the displacement sensor is that, unlike the known ones, the arm 1 is stiff and motionless, and the arm 2 is flexible and movable (Fig. 2 a). The last one is a strain gauge beam (Fig. 2 b) with glued 
semiconductor silicon crystal gauges (SSCG) which are arranged in pairs on its flat surfaces. These gauges constitute the four active arms of a measuring bridge, and a direct current (DC) excitation source $\mathrm{U}=2 \mathrm{~V}$ is used. A balancing device is also added to make any unbalance in the bridge to zero value (Fig. 3). The use of this sensor has allowed raising the sensitivity of measurements by 2 times compared with the case when a sensor with two flexible arms is used. The operating range of measurable displacement is $0 \ldots 500 \mu \mathrm{m}$ with an accuracy of $\pm 0.2 \mu \mathrm{m}$.

The kinetics of the crack was studied according to the famous standard method [5, 6]. Fatigue crack growth rate diagrams were constructed using the stress, strain, and energy parameters of fatigue fracture mechanics of materials. Within the framework of the strain approach, the dependences "fatigue crack growth rate - the local displacement at the crack tip" $\left(d a / d N-\Delta \delta_{\text {cr }}\right)$ were constructed. For this, the sensor described above fixed the size of the opening $\Delta \delta_{\text {cr }}$ along a line passing through the crack tip, while changing load from $P_{\min }$ to $P_{\max }$ in a load cycle, and the crack growth rate was determined according to the standard method.

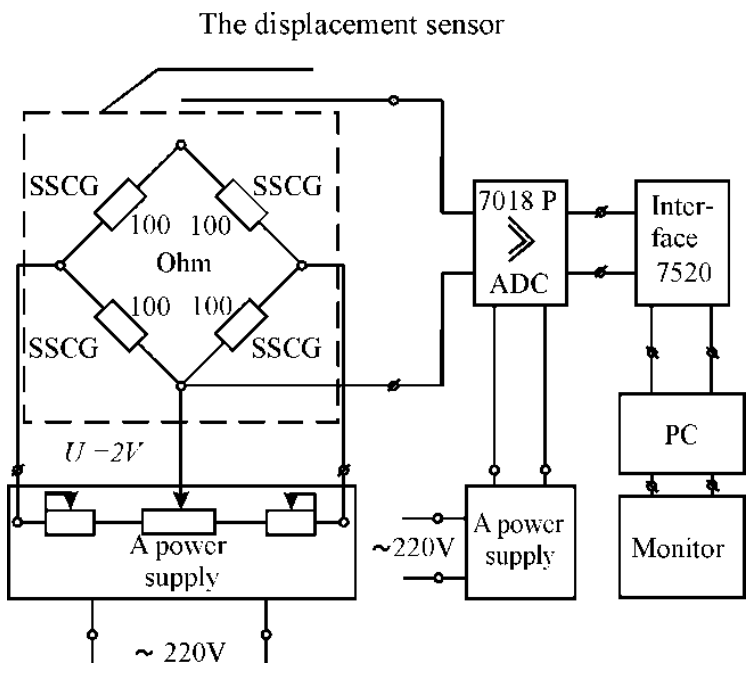

Fig. 3. The basic scheme of the measurement unit

In our opinion, the fracture process in the crack tip occurs in the zone of localization of elasticplastic strains, which is determined not by the entire plastic zone, but by the process zone of a much smaller area, the size of which $d^{*}$ is a constant of the material under the certain test conditions. Taking this into account, we propose to replace the local displacement range $\Delta \delta_{\mathrm{cr}}$ by the local strain range in the crack tip vicinity, which can be determined by the dependence:

$$
\Delta \varepsilon^{*}=\ln \left[1+\frac{\Delta \delta_{\mathrm{cr}}}{\pi \rho_{\text {eff }}}\right]=\ln \left[1+\frac{\Delta \delta_{\mathrm{cr}}}{\pi\left(\rho_{\mathrm{cr}}+d^{*}\right)}\right],
$$

where $\rho_{\text {eff }}$ is the effective radius of the crack tip; $\rho_{\mathrm{cr}}$ is the actual radius of rounding of the crack tip, which can be measured directly by the microscope; $d^{*}$ is the characteristic size of the fatigue process zone [20]. For the considered range of crack growth rates, the radius $\rho_{\mathrm{cr}}$ is small, so we assumed that $\rho_{\text {eff }}=d^{*}$.

In case of the energy approach, the loops of local mechanical hysteresis were constructed experimentally using the data of direct measuring the crack tip opening $\Delta \delta_{\text {cr }}$ in a load cycle at a certain load range $\Delta P$ applied along the specimen loading axis. It should be noted that the loops were absent at low load amplitudes while the fracture process continued to take place. Even in the absence of an experimentally established hysteresis loop (despite the use of linear displacement sensors with a measurement error of $\pm 0.2 \mu \mathrm{m}$ ), the accumulation of microplastic strains occurs followed by initiation of the fatigue crack and its growth. Taking this into account, we propose to consider the strain energy as the driving force of this process. This parameter is determined as the entire area under the load-displacement curve, that is, the total strain energy per cycle, which consists of elastic and plastic components. As a result, the dissipation range of the total energy of local strain in a load cycle in the crack tip was established as follows. During a load cycle, a $(P, \delta)$ - data set was fixed on a personal computer using the measuring system (Fig. 3). Then, taking into account the nature of the fracture localization, it was converted into a $\left(\sigma_{\mathrm{y}}, \delta\right)$ - data set using a formula:

$$
\sigma_{y}=1,128 K(P, a) / \sqrt{d^{*}} .
$$

Subsequently, all these points were approximated by a polynomial of degree 3 . By integrating the obtained curve in the range from $\delta_{\min }$ to $\delta_{\max }$ and subtracting the area $\sigma_{y \min } \cdot\left(\delta_{\max }-\delta_{\text {min }}\right)$, we obtain a value of the local strain energy $\Delta W^{*}$ (Fig. 4).

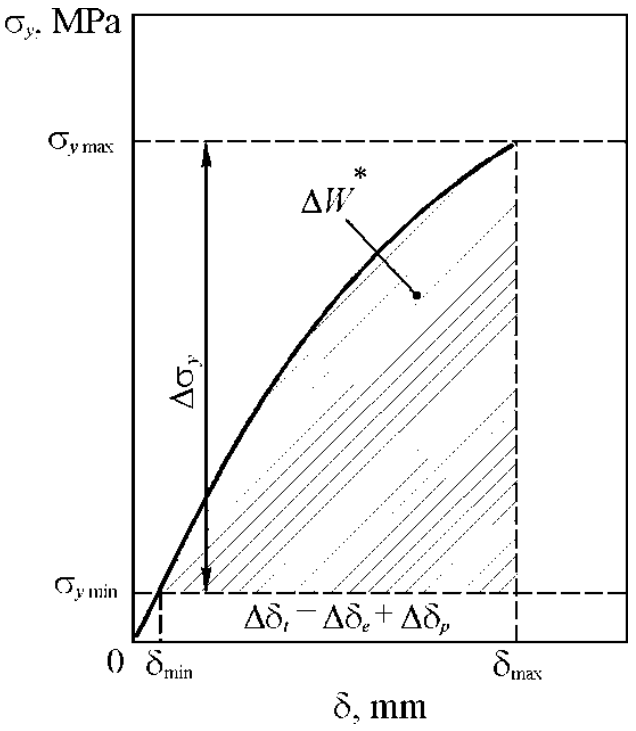

Fig. 4. A diagram for determination of complete local strain energy $\Delta W^{*}$ in the crack tip vicinity per a load cycle 


\section{RESULTS AND DISCUSSION}

On the basis of experimental research, for each variant of the steel heat treated after various modes fatigue crack growth rate diagrams were constructed basing on the presented above stress, strain and energy approaches (Fig. 5).

It can be seen for each case that the local parameters of fatigue fracture mechanics $(\Delta K, \Delta \delta$, $\left.\Delta \varepsilon^{*}, \Delta W^{*}\right)$ proposed by us, show a good correlation with fatigue crack growth rate, and the obtained dependences on the mid-amplitude sections of the diagrams are described by the corresponding equations of the Paris type:

$$
\begin{aligned}
& d a / d N=C_{1}(\Delta K)^{n_{1}}, \\
& d a / d N=C_{2}(\Delta \delta)^{n_{2}}, \\
& d a / d N=C_{3}\left(\Delta \varepsilon^{*}\right)^{n_{3}} \\
& d a / d N=C_{4}\left(\Delta W^{*}\right)^{n_{4}} .
\end{aligned}
$$
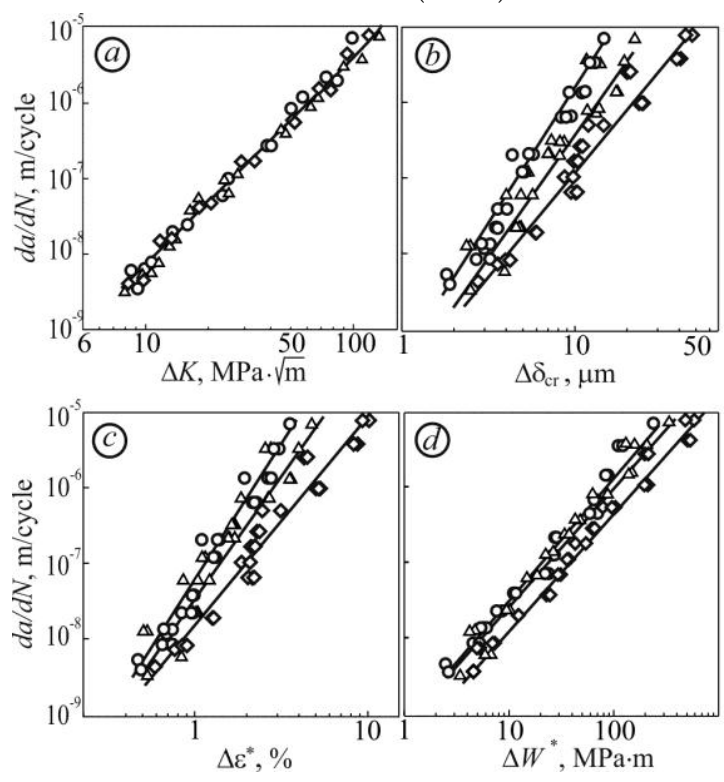

Fig. 5. Fatigue crack growth rate diagrams for a wheel steel after isothermal quenching followed by tempering at a temperature $450{ }^{\circ} \mathrm{C}(\mathrm{O}), 500{ }^{\circ} \mathrm{C}(\diamond), 550{ }^{\circ} \mathrm{C}(\triangle)$. The diagrams have been constructed using (a) the stress, (b, c) strain, and (d) energy approaches

The coefficients $C_{\mathrm{i}}$ and $n_{\mathrm{i}}$ of the equations corresponding each approach are given in Table 2 .

The analysis of the diagrams shows (Fig. 5 b, c) that for the railway wheel steel the $d a / d N-\Delta \delta$, $d a / d N-\Delta \varepsilon^{*}$, and $d a / d N-\Delta W^{*}$ dependences are more sensitive to different heat treatment modes than the $d a / d N-\Delta K$ dependences obtained using the traditional stress approach (Fig. 5 a). This makes it possible to more effectively optimize the material treatment mode according to the characteristics of the fatigue crack growth resistance. It was found that the optimum tempering temperature for such high-strength wheel steel is $500{ }^{\circ} \mathrm{C}$. This result is completely consistent with the results obtained earlier [21], what is explained by the optimal strengthening of the steel with formation of coherent precipitations of vanadium carbides and carbonitrides at a temperature of $500{ }^{\circ} \mathrm{C}$.

\begin{tabular}{|c|c|c|c|c|}
\hline \multirow{2}{*}{\multicolumn{2}{|c|}{$\begin{array}{l}\text { Material heat } \\
\text { treatment } \\
\text { mode }\end{array}$}} & \multicolumn{3}{|c|}{$\begin{array}{l}\text { Tempering at a } \\
\text { temperature }\end{array}$} \\
\hline & & \multirow{2}{*}{$\begin{array}{l}450^{\circ} \mathrm{C} \\
4.8 \cdot 10^{-12}\end{array}$} & \multirow{2}{*}{$\begin{array}{l}500^{\circ} \mathrm{C} \\
4.7 \cdot 10^{-12}\end{array}$} & \multirow{2}{*}{$\begin{array}{c}550^{\circ} \mathrm{C} \\
5.2 \cdot 10^{-12}\end{array}$} \\
\hline 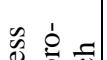 & $C_{1}$ & & & \\
\hline$\vec{\omega} \approx$ & $n_{1}$ & 3.1 & 3 & 3 \\
\hline \multirow{4}{*}{ 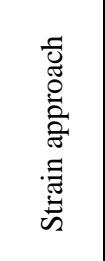 } & $C_{2}$ & $4.2 \cdot 10^{-10}$ & $2.9 \cdot 10^{-10}$ & $3.1 \cdot 10^{-10}$ \\
\hline & $n_{2}$ & 3.7 & 2.7 & 3.3 \\
\hline & $C_{3}$ & $4.3 \cdot 10^{-8}$ & $1.410^{-8}$ & $8.7 \cdot 10^{-8}$ \\
\hline & $n_{3}$ & 4.1 & 2.9 & 3 \\
\hline \multirow{2}{*}{ 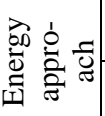 } & $C_{4}$ & $2.5 \cdot 10^{-9}$ & $1.52 \cdot 10^{-9}$ & $1.76 \cdot 10^{-9}$ \\
\hline & $n_{4}$ & 1.8 & 1.6 & 1.9 \\
\hline
\end{tabular}

Table 2. The coefficients for the analytical description of the mid-amplitude sections of the fatigue crack growth rate diagrams for the investigated materials

However, the $d a / d N-\Delta \delta, d a / d N-\Delta \varepsilon^{*}$ and $d a / d N-\Delta W^{*}$ dependences show somewhat greater data dispersion than the $d a / d N-\Delta K$ dependences obtained using the traditional stress approach. This, obviously, is due to the imperfection of measuring the crack opening characteristic by the contact method.

\section{CONCLUSIONS}

The efficiency of using the strain and energy parameters of local fracture determined by the experimental-calculation method for the diagnostics of the material state has been substantiated. These parameters can serve to properly select the material for a construction that is operated under specified conditions.

It has been established for a wheel steel tempered at different temperatures after isothermal quenching that the fatigue crack growth rate diagrams obtained using the strain and energy approaches, show better correlation with (are more sensitive to) material microstructure and its mechanical properties than the traditional diagrams obtained using the stress approach.

The optimization of heat treatment of the wheel steel has been carried out. Based on the fatigue crack growth resistance characteristics it was stated that the optimum tempering temperature for such high-strength wheel steel is $500{ }^{\circ} \mathrm{C}$.

\section{REFERENCES}

1. Ostash OP, Kulyk VV, Lenkovskiy TM, Duriagina ZA, Vira VV, Tepla TL. Relationships between the 
fatigue crack growth resistance characteristics of a steel and the tread surface damage of railway wheel. Archives of Materials Science and Engineering 2018; 90(2): 49-55

https://doi.org/ 10.5604/01.3001.0012.0662

2. Skal's'kyi VR, Rudavs'kyi DV, Yarema RY, Kanyuk YI. Distribution of mechanical stresses in a tire subjected to pressing on the wheel center of an electric locomotive. Materials Science 2018; 53(5): 623-629. https://doi.org/ 10.1007/s11003-018-0116-0

3. JIS E5402-1:2005. Railway rolling stock-Solid wheel - Part 1: Quality requirements.

4. Ostash OP, Chepil RV, Vira VV. The assessment of fatigue life of notched components at uniaxial pulsating loading using the fracture mechanics approach. International Journal of Fatigue. 2017; 105: 305-311. https://doi.org/10.1016/i.ijfatigue.2017.09.007

5. Proposed ASTM test method for measurement of fatigue crack growth rates. Fatigue Crack Growth Measurement and Data Analysis (ASTM STP 738). Philadelphia, ASTM 340-356 (1981).

6. ASTM Standard E647-99: Standard test method for measurement of fatigue crack growth rates, vol. 03.01. Annual Book of ASTM Standards 591-630 (2000). https://doi.org/ 10.1520/E0647-99

7. Elber W. Fatigue crack closure under cyclic tension. Engng. Fract. Mech. 1970; 2(1): 37-45. https://doi.org/ 10.1016/0013-7944(70)90028-7

8. Romaniv ON, Nikiforchin GN, Andrusiv B N. Effect of crack closure and evaluation of the cyclic crack resistance of constructional alloys. Soviet Materials Science. 1983; 19(3): 212-225. https://doi.org/ 10.1007/BF00723386

9. Rice JR. Mechanics of crack tip deformation and extension by fatigue. Fatigue Crack Propagation, ASTM STP 415, Am. Soc. Testing Mats. 247-311 (1967). https://doi.org/ 10.1520/STP47234S

10. Troshchenko VT, Yasnyi PV, Pokrovskii VV, Skorenko Yu. S. Methods and some results of study of fatigue-crack opening. Strength of Materials. 1987; 19(10): 1330-1336. https://doi.org/ 10.1007/BF01523230

11. Czoboly E, Csizmazia B, Havas I. Experimental determination of plastic zones. Materials Science. 1996; 32(1): 87-98. https://doi.org/ 10.1007/BF02538929

12. Vasco-Olmo JM, Díaz FA, James MN, Christopher CJ, Patterson EA. Experimental methodology for the quantification of crack tip plastic zone and shape from the analysis of displacement fields. Frattura ed Integrita Strutturale. 2017; 11(41): 166-174. https://doi.org/ 10.3221/IGF-ESIS.41.23

13. Lu Y, Lupton C, Zhu M. Tong J. In situ experimental study of near-tip strain evolution of fatigue cracks. Experimental Mechanics. 2015; 55(6): 1175-1185. https://doi.org/ 10.1007/s11340-015-0014-4

14. Yasniy PV, Marushchak PO, Pyndus Yu.I, Fostyk VB, Konovalenko IV. Patent of Ukraine №38957, Method for determining the opening at the crack tip. Published: 26.01.2009, Bulletin 2.

15. Ivanyts'kyi Ya. Mol'kov Yu, Kun' P, Lenkovs'kyi T, Wójtowicz M. Determination of the local strains near stress concentrators by the digital image correlation technique. Materials Science. 2015; 50(4): 488-495. https://doi.org/ 10.1007/s11003-015-9746-7

16. Schwalbe K, Neale B. A procedure for determining the fracture behavior of materials - the unified fracture mechanics test method EFAM GTP 94. Fatigue Fract. Engng. Mater. Struct. 1995;18(4): 413-424 https://doi.org/0.1111/j.1460-2695.1995.tb01185.x 17. Wang XG, Ran HR, Jiang C, Fang Q H. An energy dissipation-based fatigue crack growth model. International Journal of Fatigue. 2018; 114: 167-176. https://doi.org/ 10.1016/j.ijfatigue.2018.05.018

18. Gasiak G, Rozumek D. $\Delta J$-integral range estimation for fatigue crack growth rate description. International Journal of Fatigue. 2004; 26: 135-140. https://doi.org/ 10.1016/S0142-1123(03)00111-7

19. Szata M, Lesiuk G. Algorithms for the estimation of fatigue crack growth using energy method. Archives of Civil and Mechanical Engineering. 2009; 9(1): 119-134. https://doi.org/10.1016/S1644-9665(12)60045-4

20. Ravi Chandran KS. Mechanics of fatigue crack growth under large-scale plasticity: A direct physical approach for single-valued correlation of fatigue crack growth data. International Journal of Fatigue. 2018; 117: 299-313. https://doi.org/ 10.1016/j.ijfatigue.2018.08.010

21. Troshchenko VT. Nonlocalized fatigue damage to metals and alloys. Materials Science. 2006; 42(1): 20-33. https://doi.org/ 10.1007/s11003-006-0054-0

22. Ostash OP, Panasyuk VV, Andreiko IM, Chepil RV, Kulyk VV, Vira V V. Methods for the construction of the diagrams of fatigue crack-growth rate of materials. Materials Science. 2007; 43(4): 479-491. http://doi.org/ 10.1007/s11003-007-0056-6

23. All-rolled wheels. Specifications: DSTU GOST 10791-2016, M.: Standardinform (2016): (in Russian).

24. Ostash OP, Andreiko IM, Kulyk VV, Babachenko OI, Vira VV. Influence of the mode of thermal treatment and load ratio on the cyclic crack-growth resistance of wheel steels. Materials Science. 2009; 45(2): 211-219. http://doi.org/ 10.1007/s11003-0099177-4

25. Ostash OP, Muravs'kyi LI, Voronyak TI, Kmet' AB, Andreiko IM, Vira VV. Determination of the size of the fatigue prefracture zone by the method of phaseshifting interferometry. Materials Science 2011; 46(6): 781-788. https://doi.org/10.1007/s11003-011-9353-1

\section{Received 2019-02-26}

Accepted 2019-05-23

Available online 2019-05-24

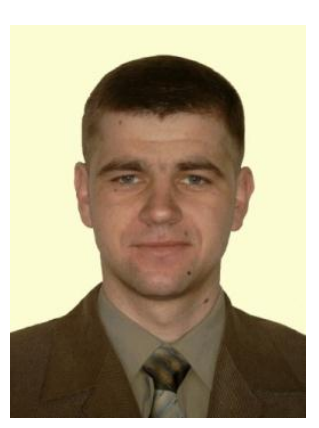

Volodymyr VIRA, Ph.D. works at Department of Strength of Materials and Structural Mechanics of Lviv Polytechnic National University, Ukraine. Prior workplace at Karpenko Physico-Mechanical Institute of National Academy of Sciences of Ukraine, Lviv. V. Vira has more than 15 years' experience of the full time scientific studies in fatigue fracture mechanics of structural materials. $\mathrm{He}$ is evaluating the fatigue durability of notched bodies on crack initiation and propagation stages. The author of about 60 scientific papers, including 2 patents. 


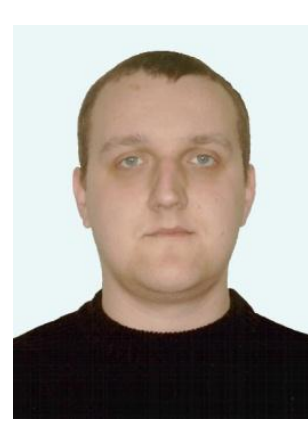

Volodymyr KULYK, Ph.D. works at Department of Applied Materials Science and Materials Engineering of Lviv Polytechnic National University, Ukraine. Prior workplace at Karpenko Physico-Mechanical Institute of National Academy of Sciences of Ukraine, Lviv, Ukraine. In scientific work, research works are carried out to evaluate the serviceability of materials under the influence of operational factors. The author of about 115 publications, including 1 book and 2 patents.

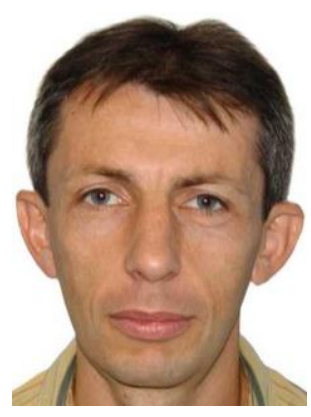

Roman CHEPIL, Ph.D. works at Karpenko PhysicoMechanical Institute of National Academy of Sciences of Ukraine (Department of Microstructural fracture mechanics of materials). The branch of scientific interests is the fatigue mechanics of material destruction, in particular the establishment of parameters of local destruction and determination of durability of structures under the action of cyclic loading. The author of about 60 scientific works and 3 patents.

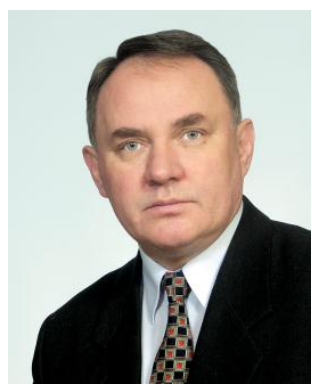

Yevhen KHARCHENKO, Prof., dr hab. eng. - works at Department of Mechanics and Bases of Designing in University of Warmia and Mazury in Olsztyn, Poland and Department of Strength of Materials, and Structural Mechanics of Lviv Polytechnic National University Ukraine. In scientific work conducts research in the theory of linear and nonlinear vibrations of discretecontinuum mechanical systems. Engaged in problems of dynamics, strength and technical diagnostics of machines and engineering structures. The author of about 300 scientific papers, including 2 monographs and 30 patents.

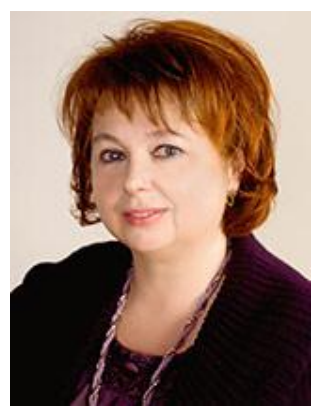

Zoia DURIAGINA, Prof., dr tech. sciences and dr hab. eng. - works at Department of Applied Materials Science and Materials Engineering of Lviv Polytechnic National University, Ukraine and Department of Physical Chemistry and Physico-Chemical Fundamentals of Environmental Engineering of The John Paul II Catholic University of Lublin, Poland. In scientific work, studies are conducted between the nano- and microstructure of the material and its physico-chemical properties, which is the main problem in the development of new materials with special properties. The author of about 235 publications, including 10 books and 16 patents. 